\title{
Optimization of Teaching Skills for Islamic Religious Education Teachers Web/Blog-Based in Improving Student Intelligence
}

\author{
Meyfi Wowor \\ Institut Pesantren KH. Abdul Chalim Mojokerto \\ email: meyfiwowor3@gmail.com \\ Husnul Khuluq \\ Institut Pesantren KH. Abdul Chalim Mojokerto \\ email: khusnul1234@gmail.com \\ Sigit Priyo Sembodo \\ Institut Pesantren KH. Abdul Chalim Mojokerto \\ email: sigitpriyono@gmail.com
}

\begin{abstract}
The teaching and learning process is complex and comprehensive. This study discusses the teaching skills of web-based Islamic education teachers/bloggers in improving student intelligence in MAN 1 Bitung which aims to reveal the stages in optimizing web-based/blog-based skills that are effective in improving student intelligence. These skills have online characteristics and include various media components in the form of text, images, sound and video which are input via the web/blog. This research is a type of qualitative research with a case study approach. Based on the results of the study that 1) optimization of teaching skills of Islamic education teachers based on web/blog in improving student intelligence is the existence of web/blog based teaching and learning using the quipper school application, which is a free online application as a meeting place for teachers and students so that the learning process is created. Obstacles faced 1. Lack of teachers in mastery of IT 2. Do not have mobile phones 3. Network problems 4. Limited internet quota 5. Mapel PAI is still manual such as Alquran hadith and Akidah Akblak. The solutions implemented were: 1. Preparing IT teachers to provide training every Saturday-Sunday, 2. Providing cellphone loans, 3. Mbps speed being increased, 4. Quota provided. $M A N$ teachers are required to master technology so that they can optimize student intelligence so that they understand more quickly and improve their competence by always updating knowledge so that they are able to face today's students.
\end{abstract}

Keywords: PAI Teacher Teaching Skills, Web Based / Blogger, Student Intelligence

\begin{abstract}
Abstrak: Proses kegiatan belajar mengajar sifatnya komplek dan menyeluruh. Penelitian ini membahas keterampilan mengajar guru PAI berbasis web/blogger dalam meningkatkan inteligensi siswa di MAN 1 Bitung yang bertujuan untuk mengungkapkan tahapan dalam optimalisasi keterampilan berbasis web/blog yang efektif dalam meningkatkan inteligensi siswa. Keterampilan ini memiliki karakteristik yang bersifat online dan mencakup berbagai komponen media berupa teks, gambar, suara dan video yang di input melalui web/blog. Penelitian ini merupakan jenis penelitian kualitatif dengan pendekatan studi kasus. Berdasarkan hasil penelitian bahwa 1)Optimalisasi keterampilan mengajar guru PAI berbasis web/blog dalam meningkatkan inteligensi siswa adalah adanya pengajaran dan pembelajaran berbasis web/blog dengan mengunakan aplikasi quipper school yang merupakan aplikasi online gratis sebagai penyedia tempat bertemunya guru dan siswa sehingga tercipta proses KBM. Hambatan yang dihadapi 1)Kurangnya guru dalam penguasaan IT 2)Tidak memiliki handphone 3)Gangguan jaringan 4)Kuota internet terbatas 5)Mapel PAI masih manual seperti Al-qur'an hadits dan Akidah Akhlak. Solusi yang terapkan yaitu: 1)Menyiapkan khusus guru IT untuk memberikan pelatihan
\end{abstract}


setiap sabtu-minggu, 2)Memberikan pinjaman handphone, 3)Ditingkatkan kecepatan Mbpsnya, 4)Disediakan kuota. Untuk guru MAN dituntut menguasai teknologi sehingga bisa mengoptimalkan inteligensi siswa supaya lebih cepat paham dan meningkatkan kompetensinya dengan selalu mengupdate pengetahuan sehingga mampu menghadapi siswa zaman now.

Kata Kunci: Keterampilan Mengajar Guru PAI, Berbasis Web/Blogger, Inteligensi Siswa

\section{PENDAHULUAN}

Era globalisasi saat ini merupakan salah satu dampak perkembangan dalam bidang teknologi dan informasi (TI). Pesatnya perkembangan hardware dan software dan berbagai aplikasi seperti bidang pendidikan, wirausaha dan perkantoran. ${ }^{1}$ Media teknologi pembelajaran telah berkembang begitu pesat dan menjadi sebuah teori serta praktik di mana proses, sumber, dan sistem belajar pada manusia baik perseorangan maupun dalam suatu ikatan organisasi dapat dirancang, dikembangkan, dimanfaatkan, dikelola, dan dievaluasi. ${ }^{2}$

Keberhasilan pendidikan tidak luput dari proses pembelajaran yang berlangsung yang didalamnya meliputi beberapa komponen yang saling berkaitan. Komponen tersebut adalah guru, siswa, materi, media dan metode atau pola penyampaian. Dalam proses pembelajaran guru dituntut untuk menciptakan suasana dengan metode yang menarik agar pembelajaran tidak membosankan. Dimana guru merupakan tenaga pendidik yang memberikan sejumlah ilmu pengetahuan kepada anak didik di sekolah. Selain memberikan ilmu pengetahuan guru juga bertugas menanamkan nilai-nilai dan sikap kepada anak didik agar anak didik memiliki kepribadian yang paripurna. ${ }^{3}$ Akan tetapi dalam proses pembelajaran guru cenderung lebih aktif daripada siswa. Siswa hanya mendengar, mencacat dan menghafal apa yang disampaikan guru. Pola seperti ini akan mengakibatkan siswa kurang bisa mengaktualisasikan dirinya dan pembelajaran akan kurang aktif. ${ }^{4}$

Belajar bukan saja dilakukan oleh individu, melainkan oleh kelompok, bahkan oleh organisasi secara keseluruhan. Belajar dapat dimana saja, kapan saja,

1 Deni Darmawan, Pendidikan Teknologi Informasi dan Komunikasi Teori dan Aplikasi, (Bandung: PT Remaja Rosdakarya, 2012), 91.

2 Bambang Warsita, Teknologi Pembelajaran Landasan dan Aplikasinya, Jakarta: Rineka Cipta, 2008), 61.

${ }^{3}$ Siswanto dan Eli Susanti, Kompetensi Pedagogik Guru Pai Dalam Menanamkan Ajaran Islam Pada Siswa Kelas Viii (Studi Kasus Di Smp Negeri I Sindang Kelingi), Jurnal Paramurobi, Vol. 1, No. 1, Januari-Juni 2018

4 Hermansyah, "Pendidikan yang Humanis", Jurnal Kependidikan Islam Fakultas Tarbiyah IAIN Sultan Syarif Qasim (Pekan Baru Riau, 2003), 18. 
dan pada siapa saja, mengenai apa saja, dengan cara dan dengan sumber apa saja yang sesuai dengan kondisi dan keperluan atau kebutuhan. ${ }^{5}$

Sekolah merupakan lembaga yang memiliki peran penting dalam dunia pendidikan yang mewujudkan keberhasilan peserta didik. Menurut Undangundang RI No. 20 tahun 2003 tentang sistem pendidikan nasional bahwa fungsi pendidikan adalah mengembangkan kemampuan dan bentuk watak serta peradaban bangsa yang bermatabat dalam rangka mencerdaskan kehidupan bangsa serta bertujuan untuk mengembangkan potensi peserta didik menjadi manusia yang beriman bertakwa kepada Tuhan Yang Maha Esa, berakhlak mulia, sehat, berilmu, kreatif, mandiri dan menjadi warga Negara yang demokratis serta bertanggung jawab. ${ }^{6}$

Mengenai pembelajaran elektronik sangat di manfaatkan teknologi dalam kegiatan pembelajaran mengajar dilakukan dengan baik guna mengarahkan kepentingan pendidikan. ${ }^{7}$ Salah satu bentuk media pembelajaran yang akan memudahkan bagi guru dan peserta didik dalam proses belajar mengajar adalah E-learning. Dalam hal ini peneliti juga mengangkat suatu proses pengajaran dan pembelajaran dengan mengunakan e-learning yang mengunakan aplikasi online seperti quipper school dalam mata pelajaran al-qur'an hadis dan akidah akhlak kelas 10 dan 11. Dengan tujuan untuk mengetahui sejauh mana keefisien dan keefektifan pembelajaran online dalam mata pelajaran a-quran hadis dan akidah akhlak.

Pembelajaran elektronik atau electronic learning telah dimulai pada tahun 1970-an. ${ }^{8}$ Berbagai istilah digunakan untuk mengemukakan pendapat tentang pembelajaran eletronik, antara lain adalah virtual learning, online learning, atau, internet-enabled learning, serta learning quipper school yang belum lama ini dikembangan di Madrasah Aliyah Negeri 1 Bitung yang menjadi lokasi penelitian penulis.

Dalam dunia pendidikan guru merupakan sarana dalam menyelenggarakan pendidikan karena guru adalah sosok yang dibutuhkan untuk menunjang keberhasilan peserta didik. Sebagus apapun kurikulum yang dirancang oleh para ahli dengan ketersediaan peralatan dan biaya yang cukup sesuai dengan pendidikannya namun pada akhirnya keberhasilan pendidikan secara professional terletak ditangan guru. Dengan demikian keberhasilan , 2008), 1.

${ }^{5}$ Bambang Warsita, Teknologi Pembelajaran Landasan dan Aplikasinya, (Jakarta: Rineka Cipta

6 Undang-undang Sisdiknas Bab II pasal 3 (Jakarta: Sinar Grafika, 2003).

7 PPs UINSA, Inovasi Pendidikan dan Pembelajaran, (Surabaya: IMTIYAZ, 2014), 257.

8 PPs UINSA, Inovasi Pendidikan dan Pembelajaran, 258. 
pendidikan tergantung pada tanggunjawab guru dalam mengembankan tugasnya.

Dalam buku Thomas Armstrong "Sekolah Para Juara" mendeskripsikan model pembelajaran klasik yang memunculkan asumsi-asumsi: pertama, cenderung memisahkan dan memberikan identifikasi kepada para muridnya sebagai murid yang pandai disatu sisi dan murid-murid yang bodoh disisi lain. Kedua, suasana kelas cenderung monoton dan membosankan. Hal ini disebabkan pendidik hanya berpijak pada satu atau dua kecerdasan dalam mengajar yaitu kecerdasan logika dan kecedasan verbal. Ketiga, proses pembelajaran yang kurang aktif membuat seorang pendidik kesulitan membangkitkan minat dan gairah peserta didik. ${ }^{10}$

Untuk mengatasi masalah tersebut penulis bertujuan agar pendidik harus memilih metode pembelajaran yang melibatkan siswa secara aktif baik melihat, mengamati, dan menganalisis dalam pembelajaran online melalui aplikasi quipper school. Dan salah satu metode pembelajaran yang membuat siswa aktif dalam proses pembelajaran yaitu dengan mengunakan metode inquiry. metode ini berupaya untuk menanamkan dasar-dasar berpikir pada diri siswa sehingga menjadikan siswa lebih banyak belajar sendiri, mengembangkan potensi kreativitas dan dapat memecahkan masalah. Hal ini dapat menjadikan siswa lebih aktif dalam pembelajaran sehingga diharapkan konsep yang tertanam dalam diri siswa lebih mantap sedangkan peran guru hanya sebagai fasilitator dan pembimbing dalam proses belajar.

Selama penulis melakukan studi penelitian awal di MAN 1 Bitung, terlihat bahwa proses pengajaran dan pembelajaran mengunakan aplikasi quipper school. Quipper school didirikan oleh Masayuki Watanabe Fumihiro Yamaguchi (Founder and CEO) tahun 2010. aplikasi ini untuk penerapan mengajar dan pembelajaran di MAN 1 Bitung. Karena di aplikasi quiper ini banyak pilihan menu yang sudah tersedia untuk guru. Guru bisa mengambil meteri-materi umum atau mata pelajaran PAI. Aplikasi ini juga menyediakan menu untuk guru membuat materi dan soal-soal sendiri dan memasukkan di aplikasi tersebut.

Pada era pendidikan sekarang kita sudah berada pada revolusi industri 4.0 dimana guru di era ini mempunyai posisi yang strategis. Guru sebagai orang tua kedua yang dituntut untuk mampu membimbing siswa mengarungi lautan hal.3.

${ }^{9}$ Uzer Usman Moh, "Menjadi Guru Profesional,” (Jakarta: PT. Remaja Rosdakarya, 2002),

10 Thomas Armstrong, Sekolah Para Juara; Menerapkan Multiple Intellegences (Kecerdasan Majemuk) di Dunia Pendidikan. Penerjemah: Yudhi Murtanto. (Bandung: Kaifa, 2004), hal.16. 
informasi teknologi guna menemukan ilmu pengetahuan dengan mengandalkan kemampuan intelegensi yang dimiliki siswa tersebut.

Dalam penelitian ini tidak semua jenis intelegensi yang akan di terapkan. Penulis akan mengangkat lima dari delapan intelenjensi yang akan dibahas yaitu kecerdasan linguistik verbal yang akan dimplementasikan dalam metode ceramah, kecerdasan kinestetik yang akan dimplementasikan dalam bentuk praktik, kecerdasan logis matematis, kecerdasan intrapersonal kecerdasan interpersonal yang akan diimplementasikan dalam bentuk metode diskusi dan kelompok.

Penelitian ini hanya mengukur keberhasilan dengan kognitif saja yaitu melalui penilaian secara tertulis maupun lisan. Peneliti juga menyadari bahwa keberhasilan suatu proses pendidikan tidak dapat hanya diukur melalui kognitifnya saja tetapi menyangkut keberhasilan siswa secara afektif dan terimplementasi secara psikomotor. Akan tetapi hipotesis peneliti melalui pengukuran kognitif ini akan menjadi tolak ukur agar guru mempertimbangkan hal-hal yang menyangkut KBM berbasis online.

Pemanfaatan media pembelajaran bagi siswa-siswi MAN 1 Bitung sebagai salah satu lembaga pendidikan Islam di Provinsi Sulawesi Utara sejatinya mampu mengangkat kualitas pendidikan pada madrasah dan sekolah umum tersebut. MAN 1 Bitung telah menerapkan pengunaan aplikasi quipper school pada proses pembelajaran. Quipper school merupakan Pemberian tugas dan latihan soal bahkan ujian adalah termasuk bagian dari aplikasi quipper school sebagai layanan e-learning guna mempermudah tugas dan menghemat waktu para guru di kelas.

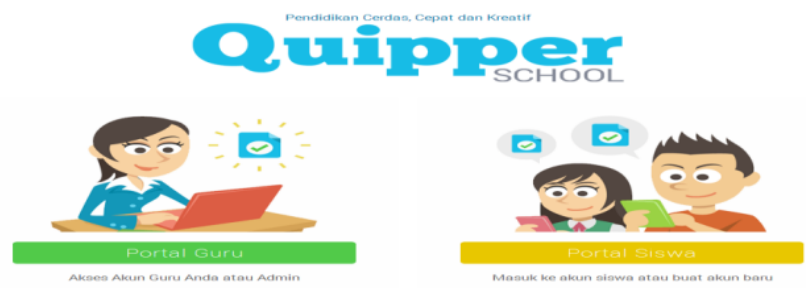

Gambar di atas, merupakan Portal pilihan guru dan siswa, yaitu dengan penerapan media pembelajaran quipper school ini dapat membentuk kemandirian belajar siswa. Madrasah Aliyah Negeri 1 Kota Bitung adalah satu satunya madrasah yang mengembangan media pembelajaran berbasis web dengan mengunakan aplikasi quipper school, maka penulis yang tentunya difokuskan pada Aktivitas MAN 1 Kota Bitung dalam memanfaatkan media aplikasi quipper school untuk pengajaran dan pembelajaran online, terutama dalam meningkatkan intelegensi siswa. 
Jenis yang akan digunakan penulis dalam penelitian ini adalah kualitatif. Penelitian kualitatif adalah penelitian yang menghasilkan data deskriptif yang berupa kata-kata tertulis atau lisan dari orang-orang dan berperilaku yang dapat diamati yang diarahkan pada latar dan individu secara bolistik (utuh)."

Data dikumpulkan melalui wawancara, pengamatan dan dokumen atau secara gabungan yang menghasilkan catatan tertulis yang akan dipilah-pilah untuk dianalisis oleh peneliti. Penelitian dilakukan di MAN 1 Kota Bitung. Sumber data penelitian diperoleh dari Ambasador Quipper School, Wakil Kurikulum dan beberapa guru PAI MAN 1 Bitung.

\section{PEMBAHASAN dan HASIL PENELITIAN}

\section{Keterampilan mengajar guru PAI berbasis web/blogger untuk meningkatkan intelejensi siswa di MAN 1 Bitung.}

Menurut Howard mengajar adalah suatu aktivitas untuk mencoba menolong, membimbing seseorang untuk mendapatkan, mengubah atau mengembangkan skill, attitude, ideals (cita-cita), appreciations (penghargaan) dan knowledge.

Dikemukakan narasumber penelitian ini keterampilan mengajar berbasis online dengan mengunakan media quipper school sebagai media yang mengkondisikan siswa untuk belajar secara mandiri. dapat mengembangkan skill dengan mengakses secara online materi yang ditugaskan oleh guru mata pelajaran. Keterampilan mengajar itu biasa, lihat dari keadaan materi, misalnya materi ini siswa belum terlalu mendapat infomasi dari luar, kita harus memperbanyak informasi-informasi dari luar, maka kita sebagai guru harus berupaya mendapatkan informasi tapi materi itu ada yang sudah tahu informasi duluan maka guru tinggal kolaborasi saja. Tapi terkadang siswa itu mudah lupa. ada materi yang mereka lupa, kita berusaha untuk memberikan pengulangan kemudian mereka ingat. ${ }^{12}$

Terkait keterampilan mengajar berbasis online dibenarkan narasumber bahwa pembelajaran mengajar online mengunakan aplikasi quipper untuk mapel PAI belum bisa dikatakan efektif contohnya mapel alquran hadis yang membutuhkan keterampilan membaca dan menulis langsung. Guru selalu tekankan pada siswa agar selalu mencatat walaupun sudah ada buku atau materi 2013), 82 .

11 Imam Gunawan, Metode Penelitian Kualitatif: Teori dan Praktik (Jakarta: Bumi Aksara,

12 Wawancara dengan Wadan Anuli selaku Waka kurikulum tanggal 18 mei 2019. 
yang difotocopikan. Itu agar mereka terbiasa menulis arab dan tidak kaku dan untuk membaca saya lebih memilih mendengarkan langsung bacaan mereka sembari membenarkan tajwid dan makraj hurufnya.

Menurut Deborah Loewenberg Ball Keterampilan Dasar Mengajar (Generic Teaching Skill) yaitu keterampilan yang bersifat generik atau yang harus dikuasai oleh setiap guru terlepas dari tingkat kelas dan mata pelajaran yang diajarkan

Dikemukakan narasumber dalam media pembelajaran di butuhkan komunikasi karena proses komunikasi antara guru dan siswa melalui bahasa verbal sebagai media utama penyampaian materi pembelajaran. Dalam kondisi penerapan pembelajaran sangat tergantung kepada guru sebagai sumber belajar. Guru dapat mengunakan alat bantu lainnya dalam menyampaikan pengajaran seperti media atau alat peraga. Media yang digunakan bervariasi. Dalam mapel akidah akhlak media yang digunakan bersifat non-materi berupa keteladanan, perintah dan larangan, ganjaran atau hukuman. Non materi ini bersifat abstrak dan hanya dapat diwujudkan melalui perbuatan dan tingkah laku guru kepada siswa. Seperti media contoh teladan yang dilakukan rasullah dalam menanamkan aqidah agar dapat diterima dengan mudah oleh umatnya. Perbuatan-perbuatan baik nabi sendiri (uswatun khasanah) atau "demonstrasi" dalam dunia pendidikan yaitu memberikan contoh dan menunjukkan tentang cara berbuat atau melakukan sesuatu. Misalnya praktek sholat sebagai sumber media yang digunakan untuk mengajarkan syiar agama kepada umatnya.

Pada prinsipnya kalau menyangkut ujian, itu semua sudah mengunakan online, yang kelas 10 dan 11 ada yang masih manual ada yang sudah online, tergantung gurunya. Untuk PAI sama juga ada yang sudah online ada yang belum, kecuali mapel al-qur'an hadits, Karena untuk menghafal ayat-ayat tidak bisa mengunakan online, harus manual. ${ }^{13}$

Terkait pembelajaran PAI online dalam meningkatkan intelegensi siswa belum efektif. Hal ini di buktikan karena masih ada keterampilan mengajar yang masih manual. Ada juga yang perlu di perhatikan oleh lembaga yaitu kurangnya pemahaman guru-guru pada pembelajaran online dan perlu pelatihan yang mendalam terkait dengan materi-materi yang berkaitan dengan strategi dan metode pembelajaran berbasis online

Menurut narasumber terkait keterampilan mengajar berbasis online bahwa Guru menjelaskan sedikit tentang materi dan memberikan soal online kepada siswa. Setiap materi terdapat 10 butir soal untuk di kerjakan. Soal yang tidak tuntas maka harus remedial kembali. Dan kalaupun ada yang berhalangan

${ }^{13}$ Wawancara Ambasador Quipper School bapak Zakir Hubulo, tanggal 18 mei 2019 
hadir maka guru akan mengirimkan soal melalui via email kepada siswa tersebut. Adapun siswa yang belum mengerti tentang pembelajaran online ini maka guru akan membimbing siswa tersebut sampai ia mengerti betul dengan aplikasi ini. ${ }^{14}$

Langkah-langkah menjalankan aplikasi quipper school tersebut adalah sebagai berikut:

Dalam pembelajaran berbasis online ada langkah-langkah untuk bisa masuk pada link aplikasi quipper school yaitu untuk penguna/guru (mendaftar) dan penguna/guru sudah terdaftar.

1. Link dan langkah-langkah menjalankan aplikasi quipper school untuk penguna/guru(mendaftar)

Ada dua cara yang harus diikuti untuk dapat mengakses aplikasi quipper school secara online, jika penguna belum terdaftar maka langkah-langkah yang harus dilakukan/pendaftar penguna baru.

a. Penguna cukup menuliskan quipper school pada link google

b. Penguna mengklik menu quipper school akan muncul link pilihan antara guru atau siswa. Karena penguna adalah guru maka yang dipilih adalah portal guru

c. Selanjutnya tampilan akan muncul link pilihan penguna sudah terdaftar maka penguna mengklik daftar sekarang atau jika sudah maka penguna mengklik masuk.

d. Link membuat akun. Link ini penguna mendaftar gratis dengan mengklik menu mulai

e. lalu akan muncul link pilihan mendaftar dengan dua cara. Penguna mengunakan akun yang ada pada facebook, maka link yang dipilih adalah hubungkan ke facebook.

Pengguna yang mengunakan akun lain selain akun facebook akan mengisi data yang diminta oleh aplikasi dengan beberapa tahap, seperti "nama depan, nama belakang, email, konfirmasi email, kode sandi, nomor telepon, kode undangan. "Kode undangan ini wajib diisi. Kode undangan diberikan oleh ambassador yang resmi dari quipper school. Jika tidak memasukan kode undangan, maka pengguna (guru) tidak dapat mengakses jawaban soal yang ada pada aplikasi quipper school'. ${ }^{15}$

\footnotetext{
${ }^{14}$ Zakir MT Hubulo, wawancara pribadi dengan Ambasador Quipper School, di ruang guru MAN 1 Kota Bitung.

${ }_{15}$ Zakir MT Hubulo, wawancara pribadi dengan Ambasador Quipper School, di ruang guru MAN 1 Kota Bitung.
} 
f. Setalah mengisi data sesuai permintaan aplikasi quipper school, penguna mengklik link lanjut.

g. Selanjutnya akan muncul link mengenal lokasi penguna. link ini mengkonfirmasi lokasi sekolah pengguna. Sekolah/madrasah secara otomatis telah terdaftar pada jaringan GPRS, untuk mencari lokasi sekolah/madrasah pengguna bisa mengisi nama sekolah/madrasah terdekat atau langsung mencari nama sekolah/madrasah pengguna pada kolom yang telah tersedia.

h. Selanjutnya tampilan link petunjuk untuk memastikan data yang di tampilkan sudah benar sehingga penguna langsung mengklik link "daftar saya"

Setelah selesai mengikuti petunjuk langkah-langkah seperti yang telah dilakukan di atas maka penguna telah terdaftar pada aplikasi quipper school dan sudah bisa mengunakan aplikasi tersebut.

2. Link dan langkah-langkah menjalankan aplikasi quipper school untuk penguna/guru (sudah terdaftar)

a. Penguna cukup menuliskan quipper school pada link google

b. Klik quipper school yang muncul di layar

c. Klik portal guru

d. Klik menu masuk yang ada di bagian kanan atas.

e. Masukkan kode akun penguna sesuai dengan akun yang digunakan ketika mendaftar, lalu klik menu masuk.

f. Memilih mapel yang akan ditugaskan kemudia klik salah satu menu yang tertuliskan pelajaran yang ada di bagian kiri (contoh kelas X 1)

g. Klik meu kurikulum untuk memilih mapel setelah itu pilih mapel yang akan ditugaskan atau dikirim pada siswa.

h. Klik menu kurikulum yang ada dibagian kanan lalu pilih menu bidang studi lain yang ada dibagian atas kanan maka akan muncul semua mapel yang ada pada aplikasi quipper school.

i. Klik mapel yang akan dikirim kepada siswa. Misalnya SMA K 13 ilmu alam lalu pilih kelas dan materi

j. Klik mapel yang di tugaskan dan kemudian klik kembali materi yang akan muncul. 
k. Membuat tugas baru maka klik menu buat tugas baru yang ada dibagian atas kanan layar lalu Tarik materi ke atas dan letakkan di kotak putih setelah itu klik menu "kirim tugas topik"

1. Mengatur lamanya waktu tugas/ujian dikerjakan lalu klik "kirim tugas ini”"

$\mathrm{m}$. Tugas/ujian sudah terkirim lalu klik menu tutup

n. Tampilan terakhir adalah mengundang siswa untuk bergabung atau dapat mengakses materi yang dikirim. Setelah itu kode dibagikan kepada siswa yang telah mendaftar diakun quipper school sesuai dengan kelas yang sudah ditentukan.

Faktor penghambat dan faktor pendukung yang dihadapi guru PAI berbasis web dalam meningkatkan intelejensi siwa di MAN 1 Bitung

\section{Faktor Penghambat}

Yang menjadi penghambat dalam keterampilan mengajar berbasis online adalah kurangnya guru dalam penguasaan IT dan Masalah ketika siswa tidak memiliki handphone karena kurang mampu. Guru guru dituntut harus bisa melakukan pembelajaran berbasis online. Sebagaimana dalam edaran menteri agama bahwa pembelajaran dan penguasaan IT itu penting. Sehingga guru dituntut agar bisa menguasai IT. ${ }^{16}$

Yang menjadi penghambat dalam keterampilan mengajar berbasis online adalah gangguan jaringan dan padam listrik karena masalah ini tidak bisa di tawar-tawar. Disaat kita merencanakan pelaksanaan tugas online maka itu bisa batal karena ketika kita sudah mengandalkan internet tiba-tiba mati listrik atau hujan yang membuat jaringan hilang.

Menurut narasumber penelitian ini walaupun pembelajaran dan pengajaran telah berbasis online tetapi untuk pembelajaran PAI belum berbasis online. Masih manual. Karena mata pelajaran PAI seperti alqur'an hadits butuh keterampilan membaca dan menulis langsung. Saya menekankan pada mereka agar selalu mencatat walaupun sudah ada buku atau materi yang difotocopikan. Itu agar mereka terbiasa menulis arab dan tidak kaku dan untuk membaca saya lebih memilih mendengarkan langsung bacaan mereka sembari membenarkan tajwid dan makraj hurufnya.

Dari narasumber ada beberapa temuan mengenai faktor penghambat dalam berbasis online yaitu: 1 . Kurangnya guru dalam penguasaan IT 2 . Tidak memiliki handphone karena kurang mampu 3. Gangguan jaringan 4. Padam

${ }^{16}$ Wawancara dengan WK 0.2 selaku Waka kurikulum di MAN 1 Bitung tanggal 18 mei 2019, pukul 12.15 . 
listrik 5. Kuota internet terbatas 6. Masih manual dalam mapel PAI seperti Alqur'an hadits dan Akidah Akhlak

\section{Faktor Pendukung}

Sama halnya dengan faktor penghambat, faktor pendukung juga tidak pernah terlepas dari setiap program yang diberlakukan. Sekurang-kurang nya faktor penghambat minimal bisa dikurangi dan diatasi dengan faktor pendukuung semaksimal mungkin.

Pembelajaran berbasis web dengan mengunakan aplikasi quipper school waka kurikulum membuat kesepakatan dimana guru-guru akan di berikan pelatihan khusus dalam IT seminggu sekali dan akan meningkatkan kapasitas mbps atau kecepatan jaringannya. Selanjutnya untuk pembelajaran PAI ada beberapa yang tidak bisa di ujian kan seperti al-qur'an hadits dan akidah akhlah karena al-quran hadits.

Menurut narasumber dalam pelaksanaan berbasis online siswa harus menyiapkan kuota untuk pembelajaran berbasis online ini, kalaupun habis tidak perlu cari diluar sekolah karena guru menyediakan kuota internet selain itu juga pembelajaran online untuk mapel al-qur'an hadits, lebih memilih manual karena kalau mengirim materi buka akun siswa menulis dan mengerjakan soal. sedangkan manual keterampilan menulis dan membaca langsung bertatap muka. Contoh: fotocopi materi, terkadang guru lebih membutuhkan buku catatan kalau hanya sekedar fotokopi siswa jadi malas untuk menulis.

Penerapan yang dilakukan informan GBS ini yang sudah di laksanakan yaitu ketika saat masuk ujian UNBK siswa harus sudah menghafalkan juz 30 yang sudah di programkan. Kalau pun belum selesai hafalan pas UNBK, siswa bisa menyetor kembali setelah UNBK karena sejatinya semua aspek yang dilakukan semata-mata untuk penanaman karakter seperti aspek menghargai, kerjasama dan gotong royong dan berkata-kata yang baik.

Faktor pendukung adalah sesuatu yang penting untuk keterampilan mengajar guru dalam meningkatkan proses intelejensi siswa dengan berbasis online. Berdasarkan wawancara dengan bapak Wadan Anuli, beliau mengatakan bahwa dalam keterampilan mengajar sudah diberlakukan pembelajaran berbasis online. Hal ini bisa di lihat dari pelaksaan UAN, MAN 1 bitung sudah menerapkan UAN BK untuk tingkat SMA dan sederajat kota bitung. Satusatunya sekolah yang menerapkan UAN BK ini, tidak hanya UAN BK, MAN 1 bitung juga sudah 3 kali mengadakan semua ujian berbasis online. Selain itu guru-guru di sini juga banyak yang menjadi instruktur pembelajaran dan 
pengajaran. Di tahun 2018 kita ditunjuk sebagai penyusun soal naskah USBN tingkat provinsi. ${ }^{17}$

Dalam pembelajaran dan mengajar berbasis web dengan mengunakan aplikasi quipper school ini banyak memberikan kemudahan karena semua materi lengkap, kurikulum lama maupun yang baru itu ada. Ribuan soal ada dan yang paling menarik adalah aplikasi ini gratis, tidak di punggut biaya. Beda dengan aplikasi ruang guru berbayar. ${ }^{18}$

\section{Solusi yang diterapkan guru PAI berbasis web/blogger dalam meningkatkan intelenjensi siswa di MAN 1 Bitung}

Untuk guru guru yang masih kurang dalam penguasaan IT maka kita menyiapkan satu guru yang bisa IT untuk memberikan bimbingan setiap hari sabtu-minggu dan guru-guru mengarahkan siswa yang tidak punya handphone untuk menghadap ke kantor dan akan memberikan pinjaman handphone kepada siswa tersebut atau kalau tidak siswa yang sudah selesai, memberi pinjam kepada siswa yang belum.

Pembelajaran PAI seperti al-qur'an masih diterapkan sistem manual karena guru membutuhkan keterampilan menulis dan membaca langsung sehingga pengucapan makroj huruf bisa di benarkan dan Guru juga menyiapkan kuota internet untuk siswa yang kekurangan kuota saat pembelajaran online. Masalah ketika siswa tidak memiliki handphone karena kurang mampu. Solusinya guru mengarahkan siswa yang tidak punya handphone untuk menghadap ke kantor dan akan memberikan pinjaman handphone kepada siswa tersebut atau kalau tidak siswa yang sudah selesai, memberi pinjam kepada siswa yang belum.

Berdasarkan permasalahan yang di atas bahwa madrasah berusaha menemukan solusi pemecahan sebagai aternatif dalam meningkatkan intelenjensi siswa berbasis online melalui optimalisasi keterampilan mengajar guru dengan mengunakan aplikasi quipper school yang afektif dan menyenangkan.

\section{KESIMPULAN}

Berdasarkan hasil penelitian yang telah dilakukan oleh peneliti di MAN 1 Bitung yaitu Optimalisasi Keterampilan Mengajar Berbasis Web/Blog dalam meningkatkan intelejensi siswa dapat di disimpulkan sebagai berikut:

17 Wawancara dengan WK 0.2 selaku Waka kurikulum di MAN 1 Bitung tanggal 18 mei 2019, pukul 12.15 .

${ }^{18}$ Wawancara dengan WK 0.2 selaku Waka kurikulum di MAN 1 Bitung tanggal 18 mei 2019, pukul 12.15 . 
Optimalisasi keterampilan guru berbasis web/blog dalam meningkatkan intelenjensi siswa di MAN 1 Bitung adalah adanya pengajaran online dengan mengunakan aplikasi quipper school ini guru dapat mengaktualisasikan diri untuk mampu membimbing siswa guna menemukan ilmu pengetahuan informasi dan teknologi.

Keterampilan mengajar guru di kelas itu sudah menjadi hal yang lumrah tanpa sistem internet, guru MAN 1 bitung di tuntut harus ikuti perkembangan tekhnologi pembelajaran karena dilihat dari keadaan siswa yang belum terlalu banyak mendapat informasi dari luar. untuk itu kita sebagai guru harus melek dalam berbagai bidang untuk menguasai literasi dasar, sains, budaya yang di aplikasikan dalam era revolusi industri 4.0 yang lebih mengutamakan teknologi.

Dengan adanya aksesbilitasi yang cepat, kita bisa menciptakan akses pembelajaran yang menyenangkan melalui video pembelajaran seperti youtube, blog atau metode online yang lain sehingga siswa mampu lebih menjadi berkembanqg dan semangat dan pendidikan tidak akan tertinggal.

Hambatan yang di hadapi berbasis web/blog adalah keterbatasan jaringan dan guru yang belum paham akan teknologi, kadangkala untuk menghadapi akan gangguan jaringan disaat kita memberikan tugas online kepada siswa ada saja yang terjadi, seperti mati listrik atau disaat hujan sehingga menyebabkan hilangnya jaringan, kuota terbatas, mata pelajaran PAI belum berbasis online.

Solusi yang diterapkan di MAN 1 bitung tepat ketika jaringan bermasalah adalah dengan beralih nya ke manual. Kemudian untuk guru MAN di tuntut untuk harus menguasai teknologi dalam pengajaran dan pembelajaran sehingga bisa mengoptimalkan intelek siswa supaya mereka lebih cepat paham.

\section{BIBLIOGRAFY}

Armstrong, Thomas, Sekolah Para Juara; Menerapkan Multiple Intellegences (Kecerdasan Majemuk) di Dunia Pendidikan. Penerjemah: Yudhi Murtanto. (Bandung: Kaifa, 2004),

Darmawan, Deni, Pendidikan Teknologi Informasi dan Komunikasi Teori dan Aplikasi, (Bandung: PT Remaja Rosdakarya, 2012)

Goleman, Daniel, Kecerdasan Emosional (Jakarta: PT Gramedia Pustaka Utama, 2000)

Hermansyah, "Pendidikan yang Humanis", Jurnal Kependidikan Islam Fakultas PPs Imam Gunawan, Metode Penelitian Kualitatif: Teori dan Praktik (Jakarta: Bumi Aksara, 2013)

Siswanto dan Eli Susanti, Kompetensi Pedagogik Guru Pai Dalam Menanamkan Ajaran Islam Pada Siswa Kelas Viii (Studi Kasus Di Smp Negeri I Sindang Kelingi), Jurnal Paramurobi, Vol. 1, No. 1, Januari-Juni 2018 
Tarbiyah IAIN Sultan Syarif Qasim (Pekan Baru Riau, 2003)

Tim UINSA, Inovasi Pendidikan dan Pembelajaran, (Surabaya: IMTIYAZ, 2014), Undang-undang Sisdiknas Bab II pasal 3 (Jakarta: Sinar Grafika, 2003)

Uzer, Usman Moh, "Menjadi Guru Profesional," (Jakarta: PT. Remaja Rosdakarya, 2002).

Wadan Anuli, wawancara dengan WK 0.2 selaku Waka kurikulum di MAN 1 Bitung tanggal 18 mei 2019, pukul 12.15 .

Warsita, Bambang Teknologi Pembelajaran Landasan dan Aplikasinya, (Jakarta: Rineka Cipta, 2008)

Zakir, MT Hubulo, wawancara dengan Ambasador Quipper School, di ruang guru MAN 1 Kota Bitung. 